\title{
Nine cystic fibrosis patients homozygous for the CFTR nonsense mutation R1162X have mild or moderate lung disease
}

\author{
P Gasparini, G Borgo, G Mastella, A Bonizzato, M Dognini, P F Pignatti
}

\begin{abstract}
The clinical course of nine cystic fibrosis patients homozygous for the CF gene nonsense mutation $R 1162 X$ was investigated. Since this mutation should lead to an interruption in the synthesis of the cystic fibrosis transmembrane regulator (CFTR) protein, a severe clinical course was expected. All patients showed pancreatic insufficiency, while the course of the lung disease was mild to moderate. These results suggest that this form of truncated CFTR protein, still containing the regulatory region, the first ATP binding domain, and both transmembrane domains, could be partially working in the lung tissues.
\end{abstract}

Cystic fibrosis (CF) is an autosomal recessive disease with a prevalence of about 1 in 2000 live births and a carrier frequency of approximately 1 in 23 in Caucasian populations. ${ }^{1}$ At the end of 1989 , the cystic fibrosis gene was identified. On the basis of the nucleotide sequence, the CF gene was predicted to encode a 1480 amino acid membrane glycoprotein, the 'cystic fibrosis transmembrane conductance regulator' (CFTR). ${ }^{2-4}$ The deduced amino acid sequence suggests that CFTR has several functionally important regions, including two ATP binding domains, two transmembrane domains, and a highly charged domain with several potential sites for phosphorylation by protein kinases. Its structure shows homology with the ATP binding cassette transport systems. ${ }^{5}$ The function of CFTR is still unknown, even if recent studies confirm that it may well be involved in cAMP activated chloride ion transport. ${ }^{67}$

The identification of naturally occurring deleterious gene mutations and the characterisation of their relation to disease phenotypes could help us to understand the functional importance of CFTR and of its putative domains. For this purpose, patients homozygous for a specific mutation are needed, in which the phenotypic expression of the disease may be ascribed to that specific gene alteration. Unfortunately, a useful number of homozygous patients can be collected only when the particular mutation being investigated reaches a high frequency in a given population. Therefore, only the clinical correlation of the most common CF mutation, $\Delta \mathrm{F} 508,,^{8-10}$ has been described in detail so far. ${ }^{11-13}$

Several other mutations have been detected, but none of them seems to be very common. ${ }^{14}$
Among them, the R1162X nonsense mutation $^{15}$ is relatively frequent in north-eastern Italy ${ }^{14}$; therefore patients carrying this mutation on both their genes are more easily found. The R1162X mutation is characterised by the substitution of the amino acid arginine in position 1162 of CFTR with a UGA termination codon. ${ }^{15}$

Here we report our results on the correlation between the R1162X mutation and the clinical manifestations of cystic fibrosis, including meconium ileus, pancreatic function, lung involvement, growth rate, etc, as shown by the nine patients identified so far in our population who are homozygotes for the mutation. The possible pathophysiological role of the $\mathrm{R} 1162 \mathrm{X}$ mutation is discussed.

\section{Subjects and methods}

DNA TYPING

Data were collected from 187 unrelated Italian patients with cystic fibrosis attending the CF Centre in Verona. Blood samples for DNA genotyping were obtained in each family from the parents and one affected child. The diagnosis of CF was confirmed by at least two positive sweat tests, performed according to the method of Gibson and Cooke. ${ }^{16}$ Genomic DNA was prepared from whole blood by standard methods. All patients were analysed for the $\Delta$ F508 gene deletion and for the R1162X nonsense mutation. Primers for PCR were selected from the flanking intron sequence of exon $10^{4}$ and of exon $19^{15}$ for analysis of $\Delta F 508$ and R1162X, respectively. PCR was performed according to standard protocols in a thermal cycler (Perkin Elmer Cetus Co, USA). The amplified fragments corresponding to the region of $\Delta F 508$ were subjected to heteroduplex analysis. ${ }^{17}$ The presence of the $\mathrm{R} 1162 \mathrm{X}$ mutation was investigated by restriction digestion with $D d e I$, followed by fragment visualisation in $2 \%$ Nusieve agarose minigels.

\section{Clinical assessment}

PATIENTS

Out of 187 unrelated CF patients analysed for genetic mutations, nine were found to be homozygous for the R1162X mutation including a couple of brothers. This group consisted of five males and four females. Retrospective data on sweat test values, clinical features, and pancreatic involvement at diagnosis were collected. Current data at the last visit include growth and nutritional status, respiratory function, pulmonary radiological findings, and 
bacterial cultures of deep sputum. A tenth $\mathrm{R} 1162 \mathrm{X} / \mathrm{R} 1162 \mathrm{X}$ patient was not considered because he was being treated in a different centre.

\section{PANCREATIC FUNCTION}

Exocrine pancreatic function was studied by duodenal intubation and pancreatic stimulation test (Pancreozymin and secretin bolus $2 \mathrm{U} / \mathrm{kg}$ body weight). Output over $30 \mathrm{~min} / \mathrm{kg}$ body weight of bicarbonate (gasanalytic method), trypsin, chymotrypsin, and lipase (titrimetric method) were determined ${ }^{18}$ as previously described. ${ }^{11}$

Digestive function was studied by a three day fat balance or by 24 hour steatorrhoea determination with analysis of fecal fat according to the method of Van Der Kamer, modified by Jeejeebhoy et al, ${ }^{19}$ as previously described. ${ }^{11}$

CLINICAL STATUS, GROWTH, AND NUTRITION Clinical status was evaluated by the Shwachman and Kulczycki score. ${ }^{20}$ On this score the best value is 100 . Height and weight centiles and weight expressed as a percentage of ideal weight for height were computed with the use of the tables of Tanner et al. ${ }^{21}$

MECONIUM ILEUS AND OTHER COMPLICATIONS Ileal obstruction at birth requiring medical or surgical therapy was defined as meconium ileus. Other major complications typically associated with $\mathrm{CF}$ were investigated, including meconium ileus equivalent, liver disease and cholelithiasis (clinical, biochemical and ultrasonographic investigations), glucose intolerance (OGTT test) and diabetes, haemoptysis, pneumothorax (PNX), lobar atelectasis, nasal polyposis, and allergic broncopulmonary aspergillosis (ABPA).

\section{PULMONARY DISEASE}

Respiratory function was assessed in the patients over 6 years of age by the following index: FVC (forced vital capacity), FEV1 (forced expiratory volume in one second), and FEF 25-75 (forced expiratory flow rate in the middle half of expiration), expressed as a percentage of normal predicted values for height and sex, according to Hibbert et al. ${ }^{22}$

Pulmonary radiographs were evaluated using the Chrispin-Norman score ${ }^{23}$ : it ranges from 0 (no damage) to 38 which is the worst score. Onset of Pseudomonas colonisation was defined as the first 6 month period in which sputum cultures were repeatedly positive for Pseudomonas aeruginosa.

ASSESSMENT OF THE DEGREE OF PULMONARY DISEASE

In order to define the degree of pulmonary disease of the R1162X homozygotes, their last chest radiograph score values were compared to the longitudinal score centiles of a cohort of
CF patients. This cohort consisted of all the CF patients diagnosed in the Veneto and Trentino regions from 1.10 .73 to 31.12 .81 and all treated at the Verona CF Centre. They were checked by chest radiography nearly every six months. The 25 th, 50th, and 75 th centiles of the Chrispin-Norman score values were computed for 20 month subgroups from 50 to 210 months of age (individual scores within the subgroups were averaged).

Furthermore the last Chrispin-Norman score values of the nine R1162X homozygotes were compared to the last score values of 37 unselected $\Delta F 508$ homozygotes.

\section{Results}

Out of 187 unrelated patients analysed for the presence of the $\Delta F 508$ and R1162X mutations, nine homozygotes for the latter mutation were found, including a couple of brothers. Their present ages range from 5 to about 24 years.

The clinical features of these patients are shown in the table. Two of them (nos 1 and 3) were detected through neonatal screening performed with blood spot immunotrypsin and meconium lactase assays. ${ }^{24}$ Two were diagnosed through meconium ileus (nos 4 and 9), four through digestive symptoms, and only one through respiratory as well as digestive ones (no 6). One of them (no 5) had borderline sweat test results.

All the patients showed pancreatic involvement at birth. The exocrine pancreatic function, investigated in six cases by duodenal intubation, was characterised by very decreased output of enzymes and bicarbonate, and a high degree of fat loss was shown in all nine patients: all had been treated with pancreatic enzyme supplementation since diagnosis. Only two adolescent subjects had poor nutritional status (nos 5 and 7) and another had very short stature at $12 \cdot 7$ years.

The onset of respiratory symptoms occurred in all but one of the subjects after the first year of life. One of them developed pneumothorax at 16 years; he is now 18 years old and no important deterioration in respiratory function or symptoms has been observed so far. No other major respiratory complications like haemoptysis or lobar atelectasis were recorded in the whole group. Nasal polyposis was present in two sibs (nos 3 and 7) and allergic bronchopulmonary aspergillosis (ABPA) occurred in two cases (nos 4 and 5).

Lung function at the last test showed a moderately obstructive picture in three patients (nos 5, 6, and 7); there was mild obstruction in the oldest patients (nos 8 and 9) and normal or near normal respiratory function in the youngest ones (nos 2,3, and 4). The individual chest $x$ ray score at the last visit was compared to that of a CF cohort (fig 1): eight out of nine patients showed values lower than the 50th centile of the reference CF population. $\Delta F 508$ frequency in the cohort was $48 \%$. When compared to an unselected group of $\Delta$ F508 homozygotes the $x$ ray scores of the $\mathrm{R} 1162 \mathrm{X}$ homozygotes were in the mid-low range of the reference group (fig 2). 
Main clinical features of the $R 1162 X$ homozygous $C F$ patients.

\begin{tabular}{|c|c|c|c|c|c|c|c|c|c|c|}
\hline \multirow{2}{*}{\multicolumn{2}{|c|}{ Clinical data and laboratory results }} & \multicolumn{9}{|c|}{ Patients } \\
\hline & & 1 & 2 & 3 & 4 & 5 & 6 & 7 & 8 & 9 \\
\hline Sweat test (mEq/kg) & $\begin{array}{l}\mathrm{Na} \\
\mathrm{Cl}\end{array}$ & $\begin{array}{l}118 \\
109\end{array}$ & $\begin{array}{r}80 \\
100\end{array}$ & $\begin{array}{l}101 \\
103\end{array}$ & $\begin{array}{r}92 \\
105\end{array}$ & $\begin{array}{l}51 \\
68\end{array}$ & $\begin{array}{l}104 \\
105\end{array}$ & $\begin{array}{l}91 \\
93\end{array}$ & $\begin{array}{l}80 \\
94\end{array}$ & $\begin{array}{l}133 \\
114\end{array}$ \\
\hline \multicolumn{2}{|l|}{ Age at diagnosis $(y)$} & $0 \cdot 1$ & $1 \cdot 2$ & $0 \cdot 1$ & $0 \cdot 1$ & $0 \cdot 3$ & $0 \cdot 3$ & $0 \cdot 4$ & 6 & $0 \cdot 1$ \\
\hline \multicolumn{2}{|l|}{ Current age (y) } & 5 & $7 \cdot 1$ & $8 \cdot 2$ & $12 \cdot 7$ & $15 \cdot 5$ & 16.9 & $18 \cdot 1$ & $18 \cdot 2$ & 23.9 \\
\hline \multicolumn{2}{|c|}{$\begin{array}{l}\text { Diagnosis by } \\
\text { Neonatal screening } \\
\text { Meconium ileus } \\
\text { Only digestive symptoms } \\
\text { Respiratory and digestive symptoms }\end{array}$} & + & + & + & + & + & + & + & + & + \\
\hline $\begin{array}{c}\text { Pancreatic involvemen } \\
\text { Pancreatic secretion } \\
\text { Bicarbonate* } \\
\text { Lipase } \dagger \\
\text { Trypsin } \ddagger \\
\text { Fat absorption coeff } \\
\text { Steatorrhoea }(\mathbf{g} / 24 \mathrm{~h}\end{array}$ & $\begin{array}{l}\text { diagnosis } \\
\left.\text { tput } / 30^{\prime} / \mathbf{k g}\right) \\
\text { nt }(\%) \S\end{array}$ & $\begin{array}{l}\bar{z} \\
\overline{14 \cdot 6}\end{array}$ & $\begin{array}{l}\overline{-} \\
\overline{74} \\
-\end{array}$ & $\begin{array}{c}5 \cdot 3 \\
17 \cdot 9 \\
2 \cdot 7 \\
57 \\
-\end{array}$ & $\begin{array}{c}\overline{-} \\
\overline{32} \\
18 \cdot 2\end{array}$ & $\begin{array}{l}2 \cdot 4 \\
2 \cdot 1 \\
0 \\
76 \\
-\end{array}$ & $\begin{array}{c}\overline{3 \cdot 4} \\
9 \\
-9 \cdot 9\end{array}$ & $\begin{array}{r}0 \cdot 0 \\
0 \\
0 \\
56 \\
-\end{array}$ & $\begin{array}{r}- \\
0 \\
- \\
\overline{22}\end{array}$ & $\begin{array}{r}2 \cdot 7 \\
0 \\
0 \\
36 \cdot 5 \\
-\end{array}$ \\
\hline $\begin{array}{l}\text { Current weight (kg) } \\
\text { (Centile) } \\
\text { Height }(\mathrm{cm}) \\
\text { (Centile) } \\
\text { Weight/height (\% p }\end{array}$ & icted) & $\begin{array}{r}18 \cdot 2 \\
(50) \\
112 \\
(75) \\
94\end{array}$ & $\begin{array}{c}21 \cdot 6 \\
(25-50) \\
123 \\
(75) \\
92\end{array}$ & $\begin{array}{c}28 \cdot 4 \\
(75-90) \\
138 \\
(>97) \\
89\end{array}$ & $\begin{array}{l}32 \cdot 8 \\
(3-10) \\
138 \\
(3) \\
103\end{array}$ & $\begin{array}{c}46 \cdot 8 \\
(3-10) \\
169 \\
(25-50) \\
83\end{array}$ & $\begin{array}{c}50 \cdot 8 \\
(10-25) \\
163 \\
(50-75) \\
90\end{array}$ & $\begin{array}{c}43 \cdot 2 \\
(<3) \\
161 \\
(25-50) \\
79\end{array}$ & $\begin{array}{c}54 \cdot 2 \\
(10-25) \\
171 \\
(25-50) \\
90\end{array}$ & $\begin{array}{c}46 \cdot 4 \\
(3-10) \\
156 \\
(10) \\
98\end{array}$ \\
\hline $\begin{array}{l}\text { Current respiratory fu } \\
\text { CVF (\% predicted) } \\
\text { FEV } 1 \text { (\% predicted } \\
\text { FEF } 25 / 75 \text { ( } \% \text { pred }\end{array}$ & ion & $\bar{z}$ & $\begin{array}{r}86 \\
94 \\
114\end{array}$ & $\begin{array}{l}97 \\
94 \\
93\end{array}$ & $\begin{array}{l}95 \\
81 \\
56\end{array}$ & $\begin{array}{l}63 \\
45 \\
20\end{array}$ & $\begin{array}{l}79 \\
58 \\
29\end{array}$ & $\begin{array}{l}83 \\
44 \\
13\end{array}$ & $\begin{array}{l}85 \\
76 \\
58\end{array}$ & $\begin{array}{l}92 \\
75 \\
33\end{array}$ \\
\hline $\begin{array}{l}\text { Current Chrispin-Nor } \\
\text { chest } x \text { ray score } \mathscr{\|}\end{array}$ & & 5 & 7 & 4 & 14 & 12 & 9 & 14 & 16 & 16 \\
\hline Age at Pseudomonas cc & isation $(y)$ & None & 6 & None & 5 & 4 & 13 & 4 & None & 12 \\
\hline $\begin{array}{l}\text { Current Shwachman- } \\
\text { clinical score** }\end{array}$ & czycki & 90 & 83 & 97 & 76 & 56 & 69 & 68 & 73 & 75 \\
\hline Complications & & & & $\begin{array}{c}\text { Nasal } \\
\text { polyposis }\end{array}$ & $\begin{array}{l}\text { Diabetes, } \\
\text { ABPA }\end{array}$ & ABPA & & $\begin{array}{c}\text { Nasal } \\
\text { polyposis }\end{array}$ & PNX & \\
\hline
\end{tabular}

* Output $\mathrm{mEq} / 30^{\prime} / \mathrm{kg}$ (normal values $>23$ ). + Output $\mathrm{U} / 1 / 30^{\prime} / \mathrm{kg}$ (normal values $>35$ ). $\ddagger$ Output $\mathrm{mU} / 30^{\prime} / \mathrm{kg}$ (normal values $>20$ ).

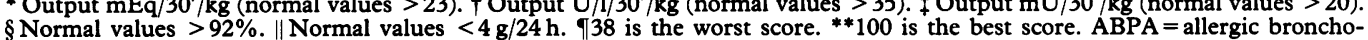
pulmonary aspergillosis. PNX= pneumothorax.

Pseudomonas colonisation occurred in six out of nine patients and its onset was recorded from 4 to 13 years of age (table). Another complication, besides two cases of meconium ileus, was insulin requiring diabetes starting at 10 years in a young CF patient (no 4).

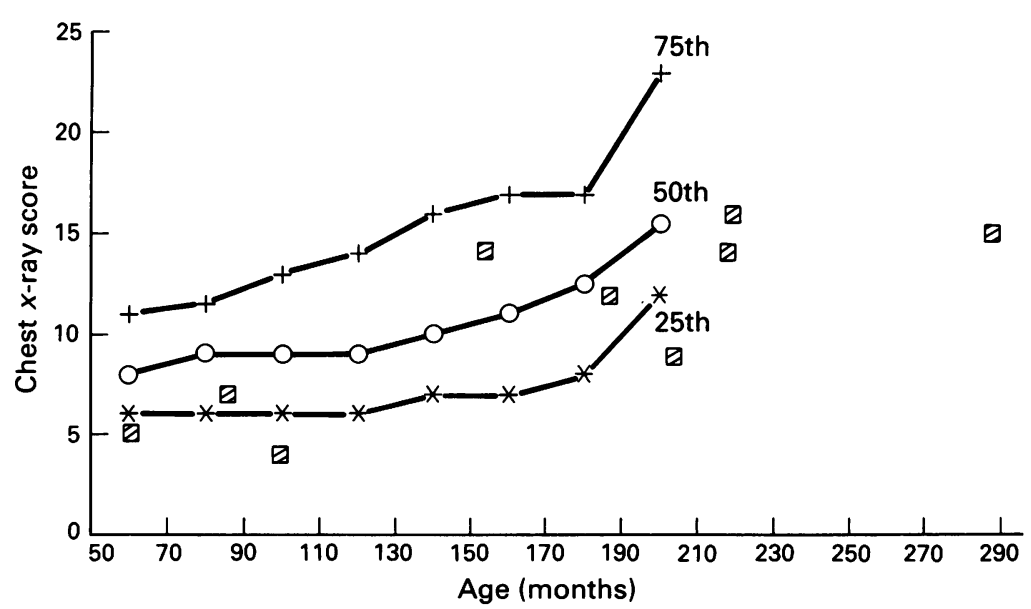

B Chest $x$-ray score in the 9 CF patients who are homozygotes for the R1162-X mutation

Figure 1 Chest $\mathrm{x}$ ray score centiles in a cohort of $121 \mathrm{CF}$ patients diagnosed in Veneto and Trentino regions from 1.10 .73 to 31.12 .81 . Chest $x$ ray score according to Chrispin-Norman (38 is the worst score). The 25th, 50th, and 75th centiles were computed for 20 month subgroups from 50 to 210 months of age. Individual scores within the subgroups were averaged.
The clinical score allowed us to classify the patients at the last check up, according to the original Shwachman-Kulczicky evaluation criteria, as follows: the three youngest patients (under 9 years) excellent or good and the remaining subjects (over 12 years) mild or fairly good.

\section{Discussion}

In this paper we describe nine patients with the R1162X nonsense mutation in each of their CFTR genes: this condition has not been described to date. This mutation involves the second half of the CFTR protein, located in exon 19 of the CF gene. Usually, nonsense mutations in human genes are associated with decreased levels of mutant messenger RNA. ${ }^{25}{ }^{26}$ Furthermore, the truncated protein produced by a nonsense mutation can be difficult to isolate, probably because of instability and rapid degradation. ${ }^{27}$ In the case of CF the difficulty of analysing the mutant gene product is increased by the fact that the CFTR gene is better expressed in selected tissues that are not easy to investigate, such as sweat gland, pancreatic, and tracheobronchial epithelial cells.

In other genetic diseases, such as haemophilia, ${ }^{28}$ the presence of nonsense mutations is frequently associated with a more severe clinical picture when compared to that associated with missense mutations. However, all the patients described here so far seem to show a mild or moderate clinical course. All but one of 


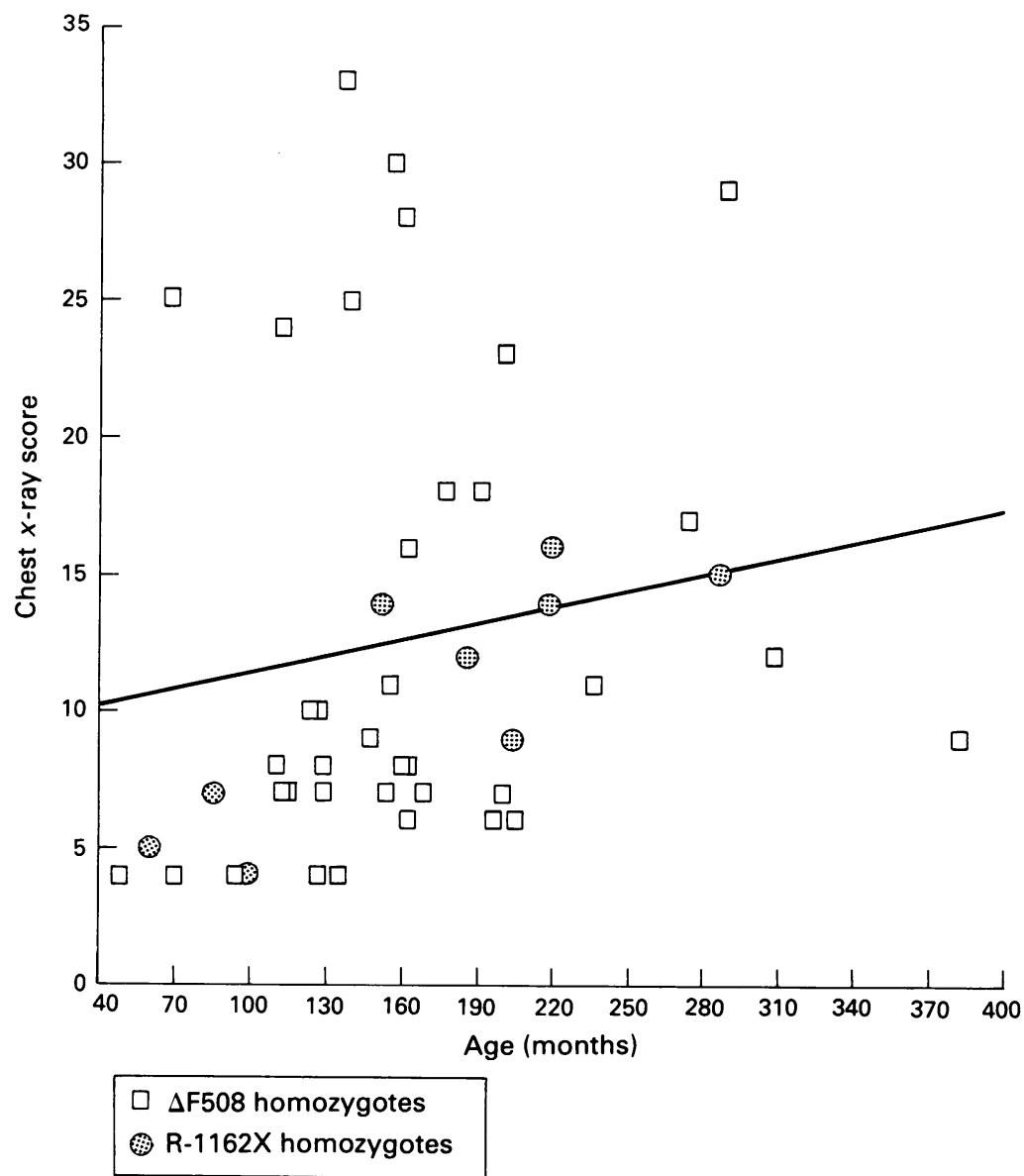

Figure 2 Last chest $x$ ray scores in nine R1162X homozygotes compared with 37 unselected $\triangle F 508$ homozygous $C F$ patients. The least square regression curve for $\triangle F 508$ homozygotes is shown $(r=0 \cdot 15)$. over the whole life span, is the best we can do at the moment. Both these approaches suggested mild or moderate lung involvement in R1162X homozygotes, though more information could be obtained from a larger R1162X group followed over a longer period.

It was easier to establish that all the $\mathrm{R} 1162 \mathrm{X}$ homozygotes in our series had severe pancreatic insufficiency, as indicated by the low level of pancreatic function and by the high degree of steatorrhoea. The overall better lung picture could not therefore be ascribed to better nutritional status, as might be the case in pancreatic sufficient patients.

It is noteworthy that among $16 \mathrm{R} 1162 \mathrm{X}$ compound heterozygote CF patients we studied, pancreatic sufficiency was found in two patients, one of whom was a compound heterozygote for R347P, and the other had a still unknown mutation. Pancreatic insufficiency was present in the remaining 14 patients, seven of whom were compound heterozygotes for $\Delta$ F508. Therefore, it seems that, with regard to the pancreatic involvement, the R1162X mutation, like $\Delta \mathrm{F} 508,{ }^{4}$ acts as a severe lack of function allele, recessive to mild, partially functional ones. R1162X, therefore, when combined with a mild mutation like $\mathrm{R} 347 \mathrm{P},{ }^{31}$ leads to pancreatic sufficiency. When combined with a severe mutation such as $\Delta \mathrm{F} 508$, pancreatic insufficiency develops.

Some hypotheses could be proposed to explain the minor pulmonary involvement in relation to the severe pancreatic damage. First, the possible presence of alternative splicing could minimise the effect of the R1162X gene mutation. Alternative splicing of the CF gene transcript involving other exons was observed in some CF tissues, but its significance, if any, in the establishment and progression of the disease has not been determined. An alternative splicing involving exon 19 of the CFTR has not been reported. A recurrent tissue specific alternative splicing, ${ }^{32}$ involving only the tracheobronchial epithelial cells, should be present in the cases described here.

The second possible explanation of the clinical phenotype stems from the observation that the truncated protein created by the $\mathrm{R} 1162 \mathrm{X}$ stop signal would still represent a large portion of the CFTR, containing both transmembrane domains, the regulatory region, and the first ATP binding domain, while missing the second nucleotide binding fold, which starts in exon 19. It is possible that this truncated protein is not degraded and is integrated into the cell membrane. ${ }^{33}$ In this case, the truncated protein could be partially functional in certain tissues, such as the lung epithelial cells. There is no evidence for such a hypothesis.

The third hypothesis is that the nonsense mutation present in $\mathrm{R} 1162 \mathrm{X}$ could be suppressed so that a reduced quantity of CFTR could be produced, as recently suggested from studies on nasal epithelial cells of two patients homozygous for the G542X nonsense mutation. ${ }^{34}$ In both cases an opal termination codon is involved. In the pulmonary epithelial 
cells of the patients described here, such suppression should be more efficient than in pancreatic epithelia.

The fourth hypothesis is that CFTR could be absent, and that other pulmonary epithelia functions of chloride ion transport could partially substitute for the missing function. No CFTR mRNA was detected in bronchial and nasal epithelial cells from a CF patient, a compound heterozygote for mutations R553X and W1316X, ${ }^{35}$ with severe pancreatic insufficiency and mild pulmonary disease as reported below. In order to determine the pathophysiology of the disease in the patients described here future studies will analyse the expression of the CF gene in different tissues.

Three recent papers are relevant to our findings. Cutting et $a l^{36}$ reported two compound heterozygotes for stop mutations S1255X/G542X and W1316X/R553X (see above), respectively. These mutations are located in exons $20,11,21$, and 11 , respectively. The patients had a mild pulmonary phenotype, meconium ileus, and severe pancreatic disease. Beaudet et $a l^{37}$ described a patient homozygous for mutation G542X with pancreatic insufficiency and pulmonary disease milder than in the average CF patient of comparable age. A patient homozygous for nonsense mutation R553X with lung function 'only moderately affected' at 13.5 years of age was reported by Bal et al..$^{38}$ These reports indicate that mild lung symptoms of the disease are not necessarily restricted to stop mutations occurring only in the terminal half of the CFTR. These reports are in agreement with the results described here, even though it is difficult to evaluate the severity of lung involvement in single cases studied over only a part of their life span.

In conclusion, the results reported here concerning nine Italian patients indicate that a termination mutation in each CF gene may be associated with a mild to moderate course of the disease, even if pancreatic and digestive functions are severely impaired.

We wish to thank the CF patients of the Cystic Fibrosis Centre in Verona and their families and we are grateful to Dr G Cabrini, coordinator of the molecular biology laboratory of the CF Centre in Verona for helpful discussions. This work was partially supported by grants from the Italian CNR Target Projects 'Biotechnologies and Bioinstrumentations' and 'Genetic Engineering'. $A B$ and $M D$ were recipients of fellowships from the Cystic Fibrosis Centre of Verona.

1 McKusick VA. Mendelian inheritance in man. 9th ed. Baltimore: Johns Hopkins University Press, 1990.

2 Rommens JM, Iannuzzi MC, Kerem BS, et al. IdentificaRommens JM, Iannuzzi MC, Kerem BS, et al. Identifica-
tion of the cystic fibrosis gene: chromosome walking and tion of the cystic fibrosis gene: chror
jumping. Science 1989;245:1059-65.

3 Riordan JR, Rommens JM, Kerem BS, et al. Identification of the cystic fibrosis gene: cloning and characterization of complementary DNA. Science 1989;245:1066-72.

4 Kerem BS, Rommens JM, Buchanan A, et al. Identification of the cystic fibrosis gene: genetic analysis. Science 1989;245:1073-80.

5 Hyde S, Emsley P, Hartshorn M, et al. Structural model of ATP-binding proteins associated with cystic fibrosis, multidrug resistance and bacterial transport. Nature 1990;346:362-5.
6 Kartner N, Hanrahan J, Jensen T, et al. Expression of the cystic fibrosis gene in non epithelial invertebrate cells produces a regulated anion conductance. Cell 1990;64:681-91.

7 Anderson M, Rich D, Gregory R, et al. Generation of cAMP-activated chloride currents by expression of CFTR. Science 1990;251:679-82.

8 Estivill X, Chillon M, Casals T, et al. DF-508 gene deletion in cystic fibrosis in Southern Europe. Lancet 1989;ii: 1404.

9 Gasparini P, Pignatti PF, Novelli G, et al. Mutation analysis in cystic fibrosis. $N$ Engl F Med 1990;323:62-3.

10 The Cystic Fibrosis Genetic Analysis Consortium. Worldwide survey of the delta-F508 mutation: report from the Cystic Fibrosis Genetic Analysis Consortium. Am $\mathcal{f}$ Hum Genet 1990;47:354-9.

11 Borgo G, Mastella G, Gasparini P, Zorzanello A, Doro R, Pignatti PF. Pancreatic function and gene deletion F508 Pignatti PF. Pancreatic function and gene dele

12 Kerem E, Corey M, Kerem BS, et al. The relation between genotype and phenotype in cystic fibrosis - analysis of the most common mutation (F508). N Engl f Med 1990;323:1517-22.

13 Johansen $\mathrm{H}$, Nir M, Hoiby $\mathrm{N}$, et al. Severity of cystic fibrosis in patients homozygous and heterozygous for F508 mutation. Lancet 1991 ;i:631-4.

14 Nunes V, Gasparini P, Novelli G, et al. Analysis of 14 cystic fibrosis mutations in five South European populations. Hum Genet 1991;87:737-8.

15 Gasparini P, Nunes V, Savoia A, et al. The search for South European CF mutations: identification of the two new mutations, four variants and intronic sequences. Genomics 1991;10:193-200.

16 Gibson LE, Cooke RE. A test for concentration of electrolytes in sweat in cystic fibrosis of pancreas utilizing lytes in sweat in cystic fibrosis of pancreas utilizing
pilocarpine by iontophoresis. Pediatrics 1959;23:545-51.

pilocarpine by iontophoresis. Pediatrics 1959;23:545-51.
17 Rommens J, Kerem B, Greer W, et al. Rapid nonradioactive detection of the major CF mutation. Am f Hum Genet 1990;46:395-6

18 Figarella C, Taulier G, Sarles H. Dosage de la chymotrypsine et de la trypsine dans le suc duodenal. Bull Soc Chim Biol 1965;47:679-84.

19 Jeejeebhoy KN, Ahmed S, Kozek G. Determination of fecal fats containing both medium and long chain triglycerides and fatty acids. Clin Biochem 1970;3:157-61.

20 Shwachman H, Kulczycki L. Long term study of one hundred and five patients with cystic fibrosis. $A m \mathcal{F} D i s$ Child 1958;96:6-15.

21 Tanner JM, Whitehouse RH, Takaishi M. Standards from birth to maturity for height, weight, height velocity and weight velocity. Arch Dis Child 1966;41:454-71.

22 Hibbert ME, Lannigan A, Landav LI, Phelan PD. Lung function values from a longitudinal study of healthy children and adolescents. Pediatr Pulmonol 1989;7:101-9.

23 Chrispin AR, Norman AP. The systematic evaluation of the chest radiograph in CF. Pediatr Radiol 1974;2:101-10.

24 Pederzini F, Faraguna D, Giglio L, et al. Development of a screening system for CF: meconium or blood serum assay or both. Acta Paediatr Scand 1990;79:935-42.

25 Baserga S, Benz E. Nonsense mutations in the human beta globin gene affect mRNA metabolism. Proc Natl Acad Sci USA 1988;85:2056-60.

26 Daar I, Maquat L. Premature translation termination mediates triosephosphate isomerase mRNA degradation. Mol Cell Biol 1988;8:802-13.

27 Adams JG, Coleman MB. Structural hemoglobin variants that produce the phenotype of thalassemia. Semin Hematol 1990;27:229-38.

28 Gitschier J, Wood W, Shuman MA, et al. Identification of a missense mutation in the factor VIII gene of a mild hemophiliac. Science 1986;232:1415-6.

29 Santis G, Osborne L, Knight R, et al. Independent genetic determinants of pancreatic and pulmonary status in cystic determinants of pancreatic and pulmo

30 Borgo G, Mastella G, Gasparini $P$, et al. Severity of pulmonary disease in a CF Italian cohort: no influence of pulmonary disease in a CF Italian cohort: no influence of

31 Bozon D, Kristidis P, Markiewiecz D, et al. Characterization of cystic fibrosis mutations in Toronto. Am f Hum Genet 1991; suppl 4: 400A.

32 Tsui LC, Buchwald $M$. Biochemical and molecular genetics of cystic fibrosis. Adv Hum Genet 1991;20:153-266.

33 Lehrman MA, Goldstein JL, Brown MS, et al. Internalization-defective LDL receptors produced by genes with nonsense and frameshift mutations that truncate the cytoplasmatic domain. Cell 1985;41:735-43.

34 Hoogeveen AT, Veeze H, Keulemans J, et al. Possible suppression of the termination codon in CF patients with the G542X mutation. Pediatr Pulmonol 1991;suppl 6:248A.

35 Hamosh A, Trapnell BC, Zeitlin PL, et al. Severe deficiency of CFTR mRNA carrying nonsense mutations R553X and W1316X in respiratory epithelial cells of p:248A.

36 Cutting G, Kasch LM, Rosenstein BJ, et al. Two patients with cystic fibrosis, nonsense mutations in each cystic with cystic fibrosis, nonsense mutations in each cystic
fibrosis gene, and mild pulmonary disease. $N$ Engl $\mathcal{F}$ Med fibrosis gene, and

37 Beaudet A, Perciaccante R, Cutting G. Homozygous nonsense mutation causing cystic fibrosis with uniparental disomy. Am $\mathcal{F}$ Hum Genet 1991;48:1213.

38 Bal J, Stuhrmann M, Schlosser M, et al. A cystic fibrosis patient homozygous for the nonsense mutation R553X. F Med Genet 1991;28:715-7. 